\title{
Effect of Salt Tolerant Edaphic Microorganisms on Tomato Local Landraces During Germination in Osmotic Stress Conditions
}

\author{
Brigitta SCHMIDT $^{1 *}$, Ionel SAMFIRA ${ }^{1}$ \\ ${ }^{1}$ Faculty of Agriculture, Banat's University of Agricultural Sciences and Veterinary Medicine "King \\ Michael Ist of Romania” from Timişoara, 119 Calea Aradului, Timişoara, Romania; \\ *)corresponding author, e-mail: brigischmidt@yahoo.com
}

BulletinUASVM Horticulture 72(2) / 2015

Print ISSN 1843-5254, Electronic ISSN 1843-5394

DOI:10.15835/buasvmcn-hort:11361

\begin{abstract}
Soil salinization is one of the limiting factors in horticultural production. Microorganisms can confer tolerance to various stress factors, including salinity, and also improve mineral nutrition of host plants. Our researches aim to assess the effect of some salt tolerant bacteria on germination of tomato seeds in saline stress conditions. Seeds from three tomato local landraces were germinated in different concentrations of saline solutions. A part of seeds was not inoculated with any bacterium, meanwhile the rest of seeds were inoculated with three different strains of edaphic bacteria isolated from a saline soil of Timis county, Romania. From a collection of bacterial strains the three most salt resistant were used for inoculation. After 16 days the germination rate and the development of roots were assessed. In terms of germination rate, the most recommended combination in our study proved to be tomato landrace Tarnova 673-bacterial strain Rh1, which presented maximum germination rate, even at $130 \mathrm{mM} \mathrm{NaCl}$ saline solution. The length of roots was different depending on the combination of tomato-bacterium genotypes. In some cases, the same bacteria couldn't alleviate the impact of salinity on root development, meanwhile in case of the same combination, tomato landrace Tarnova 673-bacterial strain Rh1, the root length was the same in 100 $\mathrm{mM}$ and $130 \mathrm{mM}$ saline solutions as in water. The influence of microorganisms on germination of tomato seeds depends on the type of plant landrace, bacterial strain and degree of salinity so there is no general pattern in each case. Though successful plant landrace-bacterium strain combinations can be identified.
\end{abstract}

Keywords: edaphic microorganisms, osmotic stress, salt tolerance, tomato local landraces.

\section{Introduction}

Soil salinization is one of the limiting factors in horticultural production. Worldwide 800 millions of hectares, meanwhile in EU 1 million hectares of land are affected by soil salinization (FAO, 2008). Due to intensive agriculture, use of fertilizers and irrigation, many soils accumulated ions producing osmotic stress (Rengasamy and Olsson, 1993). The yield of many crop plants, including tomatoes is affected by soil salinity (Flowers and Yeo, 1995) and measures for improving the stress tolerance are needed. Microorganisms, including plant growth-promoting bacteria (PGPB) and arbuscular mycorrhizal fungi (AMF) can confer tolerance to various stress factors, including salinity, and also improve mineral nutrition of host plants. It was demonstrated that plants inoculated with microorganisms isolated from saline soil have a better tolerance to osmotic stress (Mayak et al., 2004).

\section{Aims and objectives}

Our researches aim to assesses the effect of some salt tolerant bacteria on germination of tomato seeds in saline stress conditions in order to decide which bacterial strain is the most beneficial and has the highest potential to be used as biofertilizer in future product development programs. 

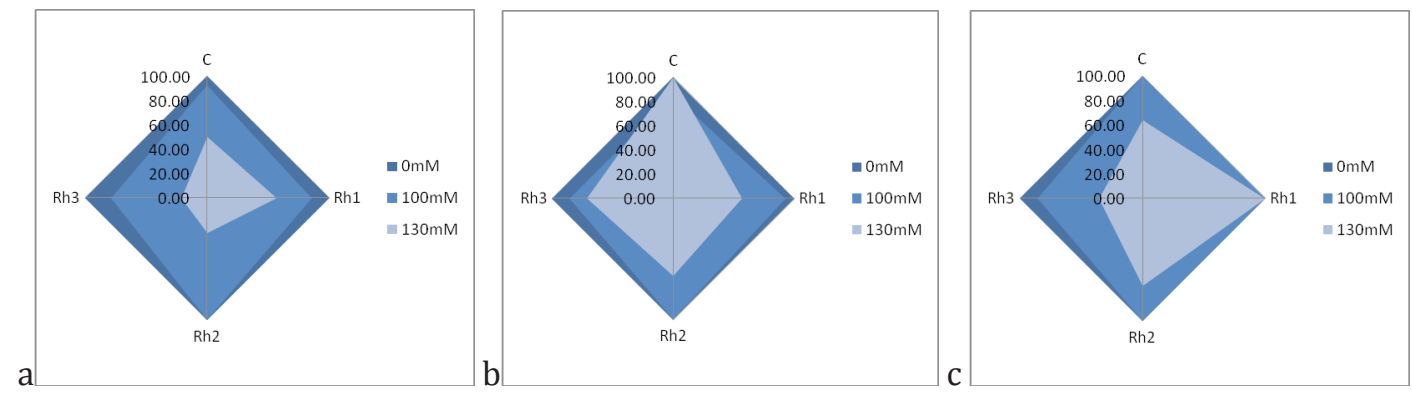

Fig. 1 Germination rate of tomato seeds (\%): left - Cruceni 102; middle - Sanmartinu Sarbesc; right - Tarnova 673.
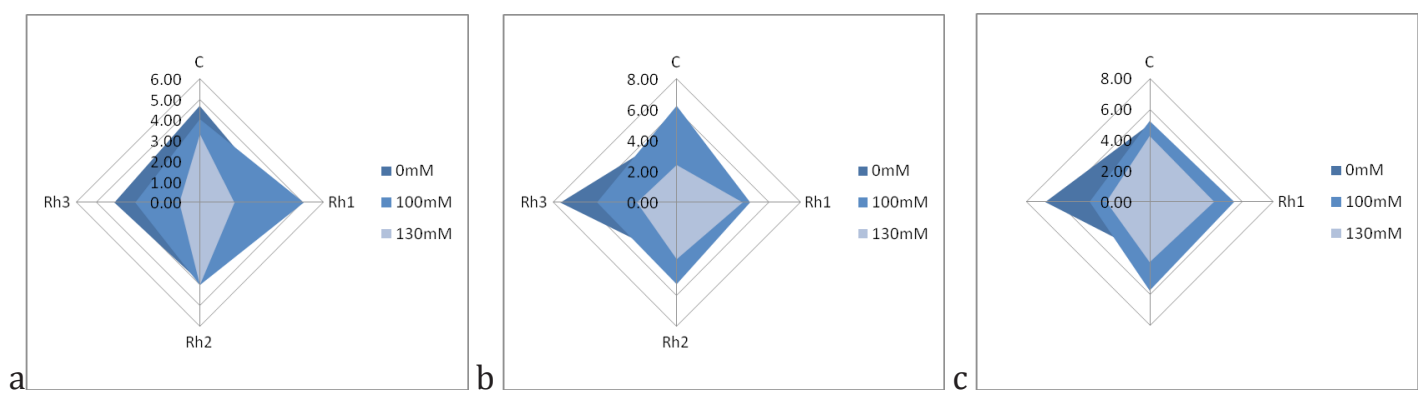

Fig. 2 Root length of tomato plantlets (cm): left - Cruceni 102; middle - Sanmartinu Sarbesc; right - Tarnova 673.

\section{Materials and methods}

Seeds from three tomatoes local landraces Cruceni 102, Sanmartinu Sarbesc and Tarnova 673 - were germinated in different concentrations of saline solutions: control $-0 \mathrm{mM} \mathrm{NaCl}, 100 \mathrm{mM}$ $\mathrm{NaCl}$ and $130 \mathrm{mM} \mathrm{NaCl}$. A part of seeds was not inoculated with any bacterium, meanwhile the rest of seeds were inoculated with three different strains of edaphic bacteria isolated from a saline soil of Timis county, Romania. The collection of bacterial strains were tested for tolerance to saline stress and the three most resistant were used for inoculation: Rh1, Rh2 and Rh3. After 16 days of germination, the germination rate and the development of roots were assessed.

\section{Results and Discussion}

In terms of gerimation rate, the most recommended combination in our study proved to be tomato landrace Tarnova 673-bacterial strain $\mathrm{Rh} 1$, which presented maximum germination rate, even at $130 \mathrm{mM} \mathrm{NaCl}$ saline solution (fig. 1).

The length of roots was different depending on the combination of tomato-bacterium genotypes. In some cases, the same bacteria couldn't alleviate the impact of salinity on root development, meanwhile in case of the same combination, tomato landrace Tarnova 673-bacterial strain Rh1, the root length was the same in $100 \mathrm{mM}$ and 130 $\mathrm{mM}$ saline solutions as in water (fig. 2).

\section{Conclusion}

We can conclude that there is no general rule for the influence of tomato seeds with salt tolerant bactaria. Even if all bacterial strains were salt tolerant, their influence was different on plants. More, even the plant genotype reacts differently on both saline solutions and inoculation with bacteria, thus successful plant landrace-bacterium strain combinations can be identified.

Acknowledgement. This paper was published under the frame of European Social Fund, Human Resources Development Operational Programme 2007-2013, project no. POSDRU/159/1.5/ S/132765.

\section{REFERENCES}

1. FAO (2008). FAO Land and Plant Nutrition Service Management. http://www.fao.org/ag/agl/agll/spush

2. Flowers TJ,Yeo AR (1995). Breeding for salinity resistance in crop plants - where next? Aust J Plant Physiol 22:875884.

3. Mayak S, Tirosh T, Glick BR (2004). Plant growthpromoting bacteria confer resistance in tomato plants to salt stress. Plant Physiol Biochem 42:565-572.

4. Rengasamy P, Olsson KA (1993). Irrigation and sodicity. Aust J Soil Res 31:821-837. 